\title{
Farklı temel besin ortamı, sitokinin ve oksin kombinasyonları, katılaştırıcı tipi ve ön soğuk uygulamalarının ekmeklik buğday (Triticum aestivum L.) çeşitlerinin anter kültüründe embriyonik kallus ve sürgün oluşumu üzerine etkileri
}

The effects of different basal medium, combinations of auxin and cytokinin, solidification types and precold treatments on embryonic callus and shoot development in bread wheat (Triticum aestivum L.) cultivars

\section{Serkan URANBEY ${ }^{1 \mathcal{O}}$ (D) , Güray AKDOĞAN ${ }^{1}(D)$, Hussein Abdullah Ahmed AHMED ${ }^{1}$ (D) Mikail ÇALIŞKAN $^{2}$ iD} ${ }^{1}$ Ankara University, Faculty of Agriculture, Department of Field Crops, Ankara, Turkey.

${ }^{2}$ Field Crops Central Research Institute, Ankara, Turkey.

MAKALE BILGISI / ARTICLE INFO

Makale tarihçesi / Article history:

DOI: $10.37908 /$ mkutbd.686209

Geliş tarihi /Received:07.02.2020

Kabul tarihi/Accepted:19.03.2020

\section{Keywords:}

Bread wheat, Triticum aestivum $\mathrm{L}$, haploid, anther, $M S, N_{6}, B_{5}$ minerals and vitamins.

Corresponding author: Serkan
URANBEY

$\triangle$ : uranbey@ankara.edu.tr

\section{ÖZET / A BSTRACT}

Atıf / Citation: Uranbey S, Akdoğan G, Ahmed HAA, Çalışkan M (2020) Farklı temel besin ortamı, sitokinin ve oksin kombinasyonları, katılaştırıcı tipi ve ön soğuk uygulamalarının ekmeklik buğday (Triticum aestivum L.) çeşitlerinin anter kültüründe embriyonik kallus ve sürgün oluşumu üzerine etkileri. MKU. Tar. Bil. Derg. 25(2) : 127-137. DOI: $10.37908 /$ mkutbd.686209

\section{GiRiş}

Ekmeklik buğday (Triticum aestivum L.)'da pek çok kültür bitkisinde olduğu gibi uygun yetişme koşullarında, çeşit özelliğine bağlı genetik yapının verim ve kaliteye etkisinin yüksek olduğu türlerden biridir. Buğday veriminin artırılmasında en önemli faktörlerden birisi de verim potansiyeli yüksek çeşitlerin kullanılmasıdır. Bölge ekolojilerine iyi uyum sağlamış, hastalık ve zararlılara dayanıklı, kuraklık, soğuk ve tuzluluk gibi stres faktörlerine toleranslı çeşitlere her zaman ihtiyaç vardır. Klasik bitki ıslahında tür içi ve dışı melezlemelerde uzun 
zaman ve işgücü gereksinimi, melezlemede yaşanan sorunlar, genetik bağlılık ve gen kaynaklarının kullanımında engellerin aşılmasında modern moleküler ıslah tekniklerine başvurulmaktadır. Çeşitlere ait farklı özelliklerin haritalanması ve bu özelliklerine ait moleküler markör geliştirme çalışmalarında durulmuş katlanmış haploid populasyonların geliştirilmesine ihtiyaç vardır. Moleküler ıslah yöntemlerin klasik bitki ıslahı programlarına entegrasyonu son derece önemlidir. Genetik saflaştırma işleminin, kısa bir sürede yapılabildiği, hibrit çeşit ıslahı programlarında zaman yönünden önemli kazanç sağlanabilmesi için etkin haplodizasyon tekniğinin geliştirilmesi son derece önemlidir (Demarly ve Sibi, 1989). Yapılan pek çok çalışmada ekmeklik buğdaylarda yüksek oranda kallus, embriyogenik kallus ve bitki rejenerasyonu üzerine genotip, besin ortamı, ön soğuk uygulaması, donor bitkilerin yetiştirildiği çevre koşullan ve karbonhidrat kaynağının etkili olduğu çok sayıda yerli ve yabancı araştırmacı tarafından belirlenmiştir (Gürel ve ark., 1993; Gu ve Liang, 1997; Hansen ve Andersen, 1998; Bölük ve Dağüstü, 2003; Patel ve ark., 2004; Kim ve Baenziger, 2005; Ahmet ve Adak, 2007; Abdallah ve ark., 2012; Lantos ve ark., 2013; Asif ve ark., 2014). Buğdayda anter kültüründe başlangıç embriyonik kallus geliştirme ortamında çok farklı temel besin ortamları kullanılmıştır (Wang ve Chen, 1986; Patel ve ark., 2004; Tuvesson ve ark., 2000; Niu ve ark., 2014). Ayrıca farklı katılaştırıcı tipi ve ön soğuk uygulamaları kullanılarak genotipe özgü protokoller rapor edilmiştir (Najia ve ark., 1997; Gu ve Liang, 1997; Saidi ve ark., 1997; Redha ve ark., 2000; Jauhar ve ark., 2009). Buğday bitkisinde haploid ve double haploid tekniğinde çok sayıda protokol geliştirilmiş olup, (Liu ve ark., 2002; Patel ve ark., 2004; Kim ve Baenziger, 2005) bitki büyüme düzenleticileri anter ya da mikrospor kültüründe son derece önemlidir. Uygun bir oksin-sitokinin dengesi sağlandığı takdirde buğday mikrosporlarının farklı tepkiler verebildiği bilinmektedir. Farklı araştırıcılar tarafından buğdayda mikrospor kültüründe sürgün oluşumunu teşvik etme amacı ile biririnden farklı oksin/sitokinin kombinasyonları kullanılmıştır (Gu ve Liang., 1997; Hansen ve Andersen, 1998; Tuvesson ve ark., 2000; Abdallah ve ark., 2012; Lantos ve ark., 2013; Asif ve ark., 2014). Bu çalışmada da ülkemizde yetiştirilen önemli ekmeklik buğday genotiplerinde, yüksek frekansta kompakt embriyogenik kallus ve sürgün oluşumu için temel besin ortamları, katılaştırıcı tipi ve ön soğuk uygulamalarını ile oksin ve sitokin konsantasyonu ve kombnasyonlarının etkilerinin belirlenmesi amaçlanmıştır.

\section{MATERYAL ve YÖNTEM}

\section{Bitki materyali}

Çalışmada materyal olarak, Tarla Bitkileri Merkez Araştırma Enstitüsü (TARM) tarafından ıslah edilmiş olan ve 2004 yılında tescil ettirilen aynı zamanda kalite özellikleri bakımından değerli bir çeşit olan Tosunbey ile 2000 yılında tescil ettirilen Demir 2000 ve Bayraktar 2000 çeşitleri kullanılmıştır.

\section{Anterlerin izolasyonu ve ön soğuk uygulaması}

Demir 2000, Tosunbey ve Bayraktar 2000 çeşitlerinde (Anterlerin yaprak kınından çıkmadığı ya da az miktarda çıktığı mikrospor çekirdek dönemi) en üstten ikinci boğum arasının ortasından kesilerek alınmıştır. Bir demet haline getirilen başaklar, su dolu bir beher içerisine konmuş ve alüminyum folyo ile sarılmıştır. Hazırlanan bu örnekler 4 ve 7 gün süreyle $4{ }^{\circ} \mathrm{C}^{\prime}$ de ön soğuk uygulamasına tabi tutulmuştur.

\section{Anterlerin sterilizasyonu}

Seradan toplanan başaklar steril kabin içerisinde \% 70'lik etil alkol içerisinde $5 \mathrm{dk}$ steril edilmiş, daha sonra $3 \mathrm{kez}$ steril saf su ile durulanmıştır. Tarladan toplanan başakçıklar ise \% 50'lik çamaşır suyu içerisinde (\% 5'lik sodyum hipoklorit içeren) 5 dakika bekletilerek 3 kez steril saf su ile tekrar durulanmıştır. Daha sonra kabin içerisinde \% 70'lik etil alkol içerisinde 1-2 dk steril edilmiş ve 3 defa daha steril saf su ile durulanmıştır. Başakçık içerisinde bulunan anterler pens yardımıyla çıkarılarak besin ortamına yerleştirilmiştir. Anterler üç farklı geliş̧me dönemine ayrılmış, başakların yaprak kınından çıkmadığı veya en fazla \% 20'ye kadar çıktığı dönem alınmıştır (Şekil 1.).

\section{Embriyogenik kallus teşviki}

Yüzey sterilizasyonuna tabi tutulan anterler, kallus oluşturma ortamına aktarılmıştır. Kallus oluşturma temel besin ortamı olarak, $M S, B_{5}$ ve $N_{6}$ mineralleri ve vitaminleri kullanılmıştır. Anterlerin tamamı 10 gün boyunca sıvı kallus teşvik başlangıç ortamında (KTBO) ( $M S$ mineral ve vitaminleri veya $B_{5}$ mineral ve vitaminleri veya $\mathrm{N}_{6}$ mineral ve vitaminleri ve $0.5 \mathrm{mg} \mathrm{L}^{-1}$ Pikloram, 2.0 $\mathrm{mg} \mathrm{L}^{-1}$ 2,4-D, $100 \mathrm{mg} \mathrm{L}^{-1}$ Kazein, $20 \mathrm{~g} \mathrm{~L}^{-1}$ sukroz, $1.2 \mathrm{~g} \mathrm{~L}^{-1}$ Proline ) kültüre alınmıştır. 10 gün sonra anterler alınarak hangi temel besin ortamı içeren kallus başlangıç teşvik ortamında muamele edilmiş ise, aynı temel besin ortamını içeren ancak modifiye edilmiş, sıvı, agar ile yarı katılaştırılmış ve gelrite ile yarı katılaştırılmış kallus teşvik ortamlarına aktarılmış olup kallus üzerinde adventif sürgünler oluştuktan sonra köklendirilirmiştir. (Çizelge 
1). Anterler, $26-28{ }^{\circ} \mathrm{C}$ de karanlıkta, $8-14$ hafta süre ile inkübasyona alınmıştır.

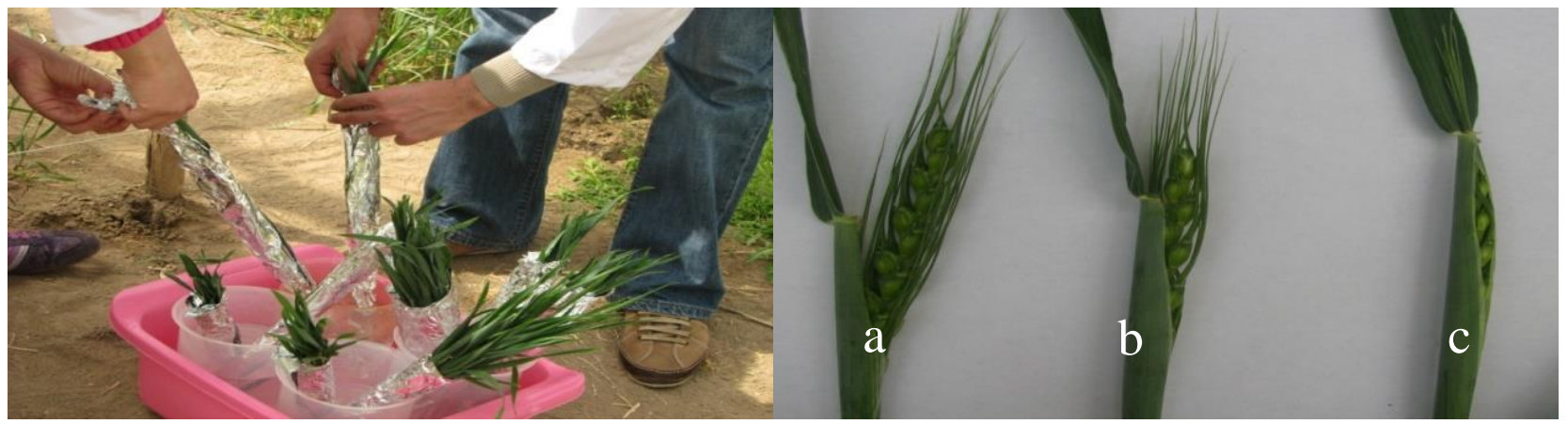

Şekil 1. Anterlerin izolasyonu ve dönemsel olarak gruplandırılması a) Anterlerin yaprak kınından $\% 60-80$ arasında çıktığı b) Anterlerin yaprak kınından \% 30-50 arasında çıktığı dönem c) Anterlerin yaprak kınından çıkmadığı veya \% 20’ye kadar çıktığı dönem

Figure 1. Isolation and devolepment stage of anthers a) The first stage when the anthers emerge from the leaf sheath between $60-80 \% \mathrm{~b}$ ) The second stage when the anthers emerge from the leaf sheath between $30-50 \% \mathrm{c}$ ) The third stage when the anthers emerge from leaf sheath up to $20 \%$

Çizelge 1. Anter kültürü çalışmalarından elde edilen kallus oluşumu için hazırlanan besin ortamları

Table 1. Callus induction media used in anthers culture studies

\begin{tabular}{|c|c|c|c|c|}
\hline $\begin{array}{l}\text { Embriyonk kallus } \\
\text { ortamı }\end{array}$ & Temel besin or & tamı & $\begin{array}{l}\text { Oksin ve oksin analogları, karbonhidrat } \\
\text { kaynakları }\end{array}$ & Katılaştırıcı tipi \\
\hline $\begin{array}{l}\text { Kallus teşvik ortamı } \\
\text { (KTO) } \mathrm{M}_{1}\end{array}$ & $\begin{array}{l}\text { MS mineral } \\
\text { vitaminleri }\end{array}$ & ve & $\begin{array}{l}2.0 \mathrm{mg} \mathrm{L}^{-1} 2,4-\mathrm{D}, 500 \mathrm{mg} \mathrm{L}^{-1} \text { Kazein, } 500 \mathrm{mg} \mathrm{L}^{-1} \\
\text { Glutamine, } 200 \mathrm{mg} \mathrm{L}^{-1} \text { manitol, } 40 \mathrm{~g} \mathrm{~L}^{-1} \text { sukroz, } \\
1.2 \mathrm{~g} \mathrm{~L}^{-1} \text { Proline }\end{array}$ & Sivı \\
\hline $\begin{array}{l}\text { Kallus teşvik ortamı } \\
\text { (KTO) } \mathrm{M}_{2}\end{array}$ & $\begin{array}{l}\text { MS mineral } \\
\text { vitaminleri }\end{array}$ & ve & $\begin{array}{l}2.0 \mathrm{mg} \mathrm{L}^{-1} 2,4-\mathrm{D}, 500 \mathrm{mg} \mathrm{L}^{-1} \text { Kazein, } 500 \mathrm{mg} \mathrm{L}^{-1} \\
\text { Glutamine, } 200 \mathrm{mg} \mathrm{L}^{-1} \text { manitol, } 40 \mathrm{~g} \mathrm{~L}^{-1} \text { sukroz, } \\
1.2 \mathrm{~g} \mathrm{~L}^{-1} \text { Proline }\end{array}$ & $4 \mathrm{~g} \mathrm{~L}^{-1}$ agar \\
\hline $\begin{array}{l}\text { Kallus teşvik ortamı } \\
\text { (KTO) } \mathrm{M}_{3}\end{array}$ & $\begin{array}{l}\text { MS mineral } \\
\text { vitaminleri }\end{array}$ & ve & $\begin{array}{l}2.0 \mathrm{mg} \mathrm{L}^{-1} 2,4-\mathrm{D}, 500 \mathrm{mg} \mathrm{L}^{-1} \text { Kazein, } 500 \mathrm{mg} \mathrm{L}^{-1} \\
\text { Glutamine, } 200 \mathrm{mg} \mathrm{L}^{-1} \text { manitol, } 40 \mathrm{~g} \mathrm{~L}^{-1} \text { sukroz, } \\
1.2 \mathrm{~g} \mathrm{~L}^{-1} \text { Proline }\end{array}$ & $1.25 \mathrm{~g} \mathrm{~L}^{-1}$ gelrite \\
\hline $\begin{array}{l}\text { Kallus teşvik ortamı } \\
\text { (KTO) } B_{1}\end{array}$ & $\begin{array}{l}\mathrm{B}_{5} \text { mineral } \\
\text { vitaminleri }\end{array}$ & ve & $\begin{array}{l}2.0 \mathrm{mg} \mathrm{L}^{-1} 2,4-\mathrm{D}, 500 \mathrm{mg} \mathrm{L}^{-1} \text { Kazein, } 500 \mathrm{mg} \mathrm{L}^{-1} \\
\text { Glutamine, } 200 \mathrm{mg} \mathrm{L}^{-1} \text { manitol, } 40 \mathrm{~g} \mathrm{~L}^{-1} \text { sukroz, } \\
1.2 \mathrm{~g} \mathrm{~L}^{-1} \text { Proline }\end{array}$ & SIVI \\
\hline $\begin{array}{l}\text { Kallus teşvik ortamı } \\
\text { (KTO) } B_{2}\end{array}$ & $\begin{array}{l}\mathrm{B}_{5} \text { mineral } \\
\text { vitaminleri }\end{array}$ & ve & $\begin{array}{l}2.0 \mathrm{mg} \mathrm{L}^{-1} 2,4-\mathrm{D}, 500 \mathrm{mg} \mathrm{L}^{-1} \text { Kazein, } 500 \mathrm{mg} \mathrm{L}^{-1} \\
\text { Glutamine, } 200 \mathrm{mg} \mathrm{L}^{-1} \text { manitol, } 40 \mathrm{~g} \mathrm{~L}^{-1} \text { sukroz, } \\
1.2 \mathrm{~g} \mathrm{~L}^{-1} \text { Proline }\end{array}$ & $4 \mathrm{~g} \mathrm{~L}^{-1}$ agar \\
\hline $\begin{array}{l}\text { Kallus teşvik ortamı } \\
\text { (KTO) } B_{3}\end{array}$ & $\begin{array}{l}\mathrm{B}_{5} \text { mineral } \\
\text { vitaminleri }\end{array}$ & ve & $\begin{array}{l}2.0 \mathrm{mg} \mathrm{L}^{-1} 2,4-\mathrm{D}, 500 \mathrm{mg} \mathrm{L}^{-1} \text { Kazein, } 500 \mathrm{mg} \mathrm{L}^{-1} \\
\text { Glutamine, } 200 \mathrm{mg} \mathrm{L}^{-1} \text { manitol, } 40 \mathrm{~g} \mathrm{~L}^{-1} \text { sukroz, } \\
1.2 \mathrm{~g} \mathrm{~L}^{-1} \text { Proline }\end{array}$ & $1.25 \mathrm{~g} \mathrm{~L}^{-1}$ gelrite \\
\hline $\begin{array}{l}\text { Kallus teşvik ortamı } \\
\text { (KTO) } \mathrm{N}_{1}\end{array}$ & $\begin{array}{l}\mathrm{N}_{6} \quad \text { mineral } \\
\text { vitaminleri }\end{array}$ & ve & $\begin{array}{l}2.0 \mathrm{mg} \mathrm{L}^{-1} 2,4-\mathrm{D}, 500 \mathrm{mg} \mathrm{L}^{-1} \text { Kazein, } 500 \mathrm{mg} \mathrm{L}^{-1} \\
\text { Glutamine, } 200 \mathrm{mg} \mathrm{L}^{-1} \text { manitol, } 40 \mathrm{~g} \mathrm{~L}^{-1} \text { sukroz, } \\
1.2 \mathrm{~g} \mathrm{~L}^{-1} \text { Proline }\end{array}$ & Sivi \\
\hline $\begin{array}{l}\text { Kallus teşvik ortamı } \\
\text { (KTO) } \mathrm{N}_{2}\end{array}$ & $\begin{array}{l}\mathrm{N}_{6} \text { mineral } \\
\text { vitaminleri }\end{array}$ & ve & $\begin{array}{l}2.0 \mathrm{mg} \mathrm{L}^{-1} 2,4-\mathrm{D}, 500 \mathrm{mg} \mathrm{L}^{-1} \text { Kazein, } 500 \mathrm{mg} \mathrm{L}^{-1} \\
\text { Glutamine, } 200 \mathrm{mg} \mathrm{L}^{-1} \text { manitol, } 40 \mathrm{~g} \mathrm{~L}^{-1} \text { sukroz, } \\
1.2 \mathrm{~g} \mathrm{~L}^{-1} \text { Proline }\end{array}$ & $4 \mathrm{~g} \mathrm{~L}^{-1}$ agar \\
\hline $\begin{array}{l}\text { Kallus teşvik ortamı } \\
\text { (KTO) } \mathrm{N}_{3}\end{array}$ & $\begin{array}{l}\mathrm{N}_{6} \text { mineral } \\
\text { vitaminleri }\end{array}$ & ve & $\begin{array}{l}2.0 \mathrm{mg} \mathrm{L}^{-1} 2,4-\mathrm{D}, 500 \mathrm{mg} \mathrm{L}^{-1} \text { Kazein, } 500 \mathrm{mg} \mathrm{L}^{-1} \\
\text { Glutamine, } 200 \mathrm{mg} \mathrm{L}^{-1} \text { manitol, } 40 \mathrm{~g} \mathrm{~L}^{-1} \text { sukroz, } \\
1.2 \mathrm{~g} \mathrm{~L}^{-1} \text { Proline }\end{array}$ & $1.25 \mathrm{~g} \mathrm{~L}^{-1}$ gelrite \\
\hline
\end{tabular}


Adventif sürgün oluşumu teşviki: Kallus teşvik ortamında 7 gün süreyle soğukta muhafaza edilen anterlerden kallus üzerinde oluşan 1-2 mm çapındaki embriyoidler içeren anterler ile kallus oluşturmayan anterler aşağıdaki Sürgün gelişim ortamına (SGO) aktarıımıştır.

Sürgün gelişim ortamı (SGO): MS mineralleri ve vitaminleri $\left(1.0-2.0 \mathrm{mg} \mathrm{L}^{-1} \mathrm{BAP}\right.$ ve $1.0-2.0 \mathrm{mg} \mathrm{L}^{-1}$ Kinetin $+\left(0.25-0.50 \mathrm{mg} \mathrm{L}^{-1}\right.$ IBA ve NAA), $\% 2$ sukroz ve $7 \mathrm{~g} \mathrm{~L}^{-1}$ agar içeren besin ortamından meydana gelmiştir.

\section{istatistiki analiz}

Denemeler, tesadüf parselleri ve tesadüf bloklarında bölünmüş parseller deneme desenine göre kurulmuş olup, her muamele içerisinde 100 adet anterin bulunduğu 4 tekerrürlü $50 \times 50$ mm'lik petri kutularından oluşmuştur. Elde edilen verilere Düzgüneş ve ark. (1983) tarafından bildirildiği şekilde varyans analizi ve Duncan testi uygulanmıştır. Yüzde değerler istatistiki analizden önce açı değerlerine dönüştürülmüş (Snedecor ve Cochran, 1967) ve tüm istatistiki analizler, MSTAT-C bilgisayar programı kullanılarak yapılmıştır.

\section{BULGULAR ve TARTIŞMA}

\section{Tosunbey çeşidi anterlerinin in vitro'da kültüre alınması ve embriyonik kallus oluşumu}

Genel olarak denenen tüm ortamlarda anterlerin etrafında kültüre alındıktan 8-14 hafta sonra kallus oluşumu başlamış, 14 ila 18. haftadan sonra kallus büyüklüklerinin bariz bir şekilde arttığı görülmüştür. Tüm ortamlarda kallus büyüklükleri bakımından da bir farklılık gözlenmemiştir. Farklı temel besin ortamlarının ve ön soğuk uygulamasının kallus oluşumu üzerine etkilerine ilişkin varyans analiz sonuçlarına göre, farklı besin ortamları ve ön soğuk uygulaması, kallus oluşturan anter oranı \%1 $(P<0.01)$ düzeyinde önemli bulunmuştur. Ayrıca farklı temel besin ortamları $\times$ ön soğuk uygulaması intreaksiyonu, kallus oluşumu üzerine etkileri de \%1 ( $P$ $<0.01$ ) düzeyinde önemlidir. Çalışmada kullanılan tüm besin ortamları ve ön soğuk muamelelerinde ortalama kallus oranı \% 0-14 arasında değişmiştir (Çizelge 2). Anterlerinin oran olarak büyük bir kısmının kallus oluşturmadığı gözlemlenmiştir. Anter eksplantları yakından incelendiğinde (binoküler altında bakılarak), alt dış kavuz ya da dişicik tepesinin anter izolasyonu sırasında besin ortamına karıştığı ve bu parçacıkların kallus oluşturduğu gözlenmiş olup, bu eksplantlar ortamdan uzaklaştırılmıştır. En yüksek kallus oluşturan anter oranı \% 14 ile KTO $\left(\mathrm{N}_{1}\right)$ besin ortamından 7 gün süreyle soğukta muhafaza edilen anterlerden elde edilmiştir. En düşük kallus oranı ise \% 0 ile KTO $\left(M_{1}\right)$, KTO $\left(\mathrm{M}_{2}\right)$, KTO $\left(\mathrm{M}_{3}\right)$, KTO $\left(\mathrm{B}_{3}\right)$, KTO $\left(\mathrm{N}_{2}\right)$, KTO $\left(\mathrm{N}_{3}\right)$ besin ortamlarında hiçbir ön soğuk muamelesi uygulamayan anterler ile KTO $\left(B_{2}\right)$ ortamında 7 gün süreyle ön soğuk uygulanan anterlerden elde edilmiştir.

Çizelge 2. Farklı kallus teşvik ortamları (KTO) ve ön soğuk uygulamalarının Tosunbey çeşidinde kallus oluşumu üzerine etkileri (\%)

Table 2. Effects of different callus induction media and pre-cold treatments on callus formation in Tosunbey variety (\%)

\begin{tabular}{|c|c|c|c|c|}
\hline \multirow{2}{*}{ Besin Ortamları } & \multicolumn{3}{|c|}{ Ön soğuk uygulaması (gün) } & \multirow{2}{*}{ Ortalama } \\
\hline & 0 & 4 & 7 & \\
\hline KTO $\left(M_{1}\right)$ & $4.0 \mathrm{~b}-\mathrm{g}$ & $2.0 \mathrm{~b}-\mathrm{I}$ & $5.5 \mathrm{~b}-\mathrm{e}$ & $3.8 \mathrm{a}$ \\
\hline KTO $\left(\mathrm{M}_{2}\right)$ & 0.01 & $0.5 \mathrm{hl}$ & $4.0 \mathrm{~b}-\mathrm{h}$ & $1.5 \mathrm{~b}$ \\
\hline KTO $\left(\mathrm{M}_{3}\right)$ & 0.0 I & $1.0 \mathrm{ghı}$ & $0.5 \mathrm{hl}$ & $0.5 \mathrm{~b}$ \\
\hline KTO $\left(B_{1}\right)$ & $2.0 \mathrm{~d}-\mathrm{I}$ & $6.5 \mathrm{a}-\mathrm{d}$ & $5.5 b-f$ & $4.7 \mathrm{a}$ \\
\hline KTO $\left(B_{2}\right)$ & 0.01 & $1.0 \mathrm{f}-\mathrm{I}$ & 0.01 & $0.3 \mathrm{~b}$ \\
\hline $\mathrm{KTO}\left(\mathrm{B}_{3}\right)$ & 0.01 & $1.0 \mathrm{f}-\mathrm{I}$ & $1.5 \mathrm{e}-\mathrm{I}$ & $0.8 \mathrm{~b}$ \\
\hline $\mathrm{KTO}\left(\mathrm{N}_{1}\right)$ & $0.5 \mathrm{hı}$ & $4.0 \mathrm{~b}-\mathrm{h}$ & $14 \mathrm{a}$ & $6.2 \mathrm{a}$ \\
\hline $\mathrm{KTO}\left(\mathrm{N}_{2}\right)$ & 0.01 & $1.5 \mathrm{f}-\mathrm{I}$ & $3.5 c-1$ & $1.7 \mathrm{~b}$ \\
\hline $\operatorname{KTO}\left(\mathrm{N}_{3}\right)$ & 0.01 & $8.0 \mathrm{ab}$ & $8.0 \mathrm{ab}$ & $5.3 \mathrm{a}$ \\
\hline Ortalama & $0.7 \mathrm{~b}$ & $2.8 \mathrm{a}$ & $4.7 a$ & \\
\hline
\end{tabular}

LSD \% 5 Besin ortamları $=4.864 ;$ LSD \% 5 ön soğuk uygulaması $=2.808 ;$ LSD $\% 5$ interaksiyon $=8.425$

Besin ortamları içinde en yüksek kallus oluşturan anter oranı \% 6.2 ile KTO $\left(\mathrm{N}_{1}\right)$ sıvı besin ortamı öne çıkarken, 4 ve 7 günlük ön soğuk uygulamasının istatistiki olarak önemli derecede kallus oranını artırdığı saptanmıştır (Şekil 2.a.). En iyi embriyogenik kallus ortamı ve şartlarında gelişen embriyonik kalluslarda SGO alındıktan yaklaşık 4-6 hafta sonra sürgün uçları görülmeye başlanmış olup, sürgünler gelişinceye kadar SGO'da bırakılmıştır (Şekil 2.d.). SGO ortamına alındıktan yaklaşık 14 hafta sonra sürgünlerin uzadığı görülmüştür (Şekil 
2.f.). Farklı hormon konsantrasyonlarının, sürgün rejenerasyonu oranı, üzerine etkileri 0.01 düzeyinde istatistiki olarak önemli bulunmuştur. Farklı BAP, KIN, NAA ve IBA konsantrasyonlarının sürgün rejenerasyonu üzerinde önem düzeyini belirleyebilmek amacıyla kullanılan tüm ortamların arasında Duncan testi yapılmış ve sonuçlar Çizelge 3'te verilmiştir. (Çizelge 3)'te de görüldüğü gibi, sürgün rejenerasyon oranı (sürgün oluşturan anter oranı), \% 00.00-.7.5 arasında değişmiştir.
En yüksek sürgün rejenerasyon oranı (\% 7.5) $2 \mathrm{mg} \mathrm{L}^{-1} \mathrm{KIN}$ ve $0.50 \mathrm{mg} \mathrm{L}^{-1} \mathrm{NAA}, 2 \mathrm{mg} \mathrm{L}^{-1} \mathrm{KIN}$ ve $0.50 \mathrm{mg} \mathrm{L}^{-1} \mathrm{IBA}$, en düşük sürgün rejenerasyon oranı ise $(\% 0.00) 1.0 \mathrm{mg} \mathrm{L}^{-1}$ $\mathrm{BAP}+0.25 \mathrm{mg} \mathrm{L}^{-1} \mathrm{NAA} ; 1.0 \mathrm{mg} \mathrm{L}^{-1} \mathrm{BAP}+0.25 \mathrm{mg} \mathrm{L}^{-1} \mathrm{IBA}$; $1.0 \mathrm{mg} \mathrm{L}^{-1} \mathrm{KIN}+0.25 \mathrm{mg} \mathrm{L}^{-1} \mathrm{NAA}$ içeren $\mathrm{MS}$ besin ortamından alınmıştır. Besin ortamları, sürgün rejenerasyonu bakımından, 0.01 düzeyinde 3 grup içerisinde yer almışlardır.

Çizelge 3. Farklı büyüme düzenleyici konsantrasyon ve kombinasyonlarının Tosunbey çeşidi anterlerinde sürgün oluşumu üzerine etkileri

Table 3. Effects of different growth regulators concentrations and combinations on shoot formation in Tosunbey variety

\begin{tabular}{|c|c|c|c|c|}
\hline \multicolumn{4}{|c|}{ Büyüme düzenleyicileri ( $\left.\mathrm{mg} \mathrm{L}^{-1}\right)$} & \multirow{2}{*}{ Sürgün oluşturan anter oranı (\%) } \\
\hline BAP & Kinetin & NAA & IBA & \\
\hline 1.0 & - & 0.25 & - & 0.0 \\
\hline 2.0 & - & 0.50 & - & 0.0 \\
\hline 1.0 & - & - & 0.25 & 0.0 \\
\hline 2.0 & - & - & 0.50 & $7.5 \mathrm{a}$ \\
\hline- & 1.0 & 0.25 & - & $0.0 \mathrm{c}$ \\
\hline- & 2.0 & 0.50 & - & $7.5 \mathrm{a}$ \\
\hline - & 1.0 & - & 0.25 & $2.5 \mathrm{~b}$ \\
\hline - & 2.0 & - & 0.50 & $2.5 \mathrm{~b}$ \\
\hline
\end{tabular}

LSD $\% 5=9.444$

\section{Demir-2000 çeşidi anterlerinin in vitro'da kültüre alınması ve embriyonik kallus oluşumu}

Denenen tüm ortamlarda anterlerin etrafında kültüre alındıktan 6-12 hafta sonra kallus oluşumu başlamış, 12 ila 16. haftadan sonra kallus büyüklüklerinin bariz bir şekilde arttığı görülmüştür. Çalışmada kullanılan tüm besin ortamları ve ön soğuk muamelelerinde ortalama kallus oranı \% 0-8 arasında değişmiştir (Çizelge 4). Tüm ortamlarda kallus büyüklükleri bakımından da bir farklılık gözlenmemiştir. Tosunbey ve Bayraktar-2000 çeşidi ile karşılaştırıldığında Demir-2000 çeşidinde daha hızlı ve daha kompakt kallus oluşumu gözlenmiştir (Şekil 2.b.). Farklı temel besin ortamlarının ve ön soğuk uygulamasının kallus oluşumu üzerine etkilerine ilişkin varyans analiz sonuçlarına göre, farklı besin ortamları ve ön soğuk uygulaması, kallus oluşturan anter oranı \%1 ( $P$ $<0.01)$ düzeyinde önemli bulunmuştur. Ayrıca farklı temel besin ortamları $X$ ön soğuk uygulaması intreaksiyonu, kallus oluşumu üzerine etkileri de \%1 ( $P$ $<0.01$ ) düzeyinde önemlidir.

En yüksek kallus oluşturan anter oranı \% 8 ile KTO $\left(B_{1}\right)$ besin ortamından 7 gün süreyle soğukta muhafaza edilen anterlerden elde edilmiştir. Buna karşın, ön soğuk muamelesi uygulanmadan $M_{1}, M_{2}, M_{3}, B_{3}, N_{2}$ ve $N_{3}$ kallus teşvik edici ortamlarda kültüre alınan anterlerde, 4 gün süreyle ön soğuk muamelesi uygulanan ve $M_{2}, M_{3}, B_{1}, B_{2}$,
$B_{3}, N_{2}$ ve $N_{3}$ kalluş teşvik edici ortamlarda kültüre alınan anterler ile 7 gün süreyle ön soğuk muamelesi uygulanan ve $\mathrm{N}_{2}$ kallus teşvik edici ortamda kültüre alınan anterlerde kallus gelişimi gözlemlenememiştir. Besin ortamları içinde en yüksek kallus oluşturan anter oranları SIVI $\left(M_{1}, B_{1}\right.$ ve $\left.N_{1}\right)$ besin ortamlarından elde edilirken, 7 günlük ön soğuk ortalamasının istatistiki olarak kallus oranını artırdığı saptanmıştır (Şekil 2.c.). En iyi embriyogenik kallus ortamı ve şartlarında gelişen embriyonik kalluslarda sürgün oluşumu başlayıp sürgünler gelişinceye kadar SGO da bırakılarak 3 haftada bir besin ortamı yenilenmiştir. Kallus oluşturan ve oluşturmayan anterler her muamele içerisinde 100 adet anterin bulunduğu 4 tekerrürlü $90 \times 90 \mathrm{ml} l$ lik petri kutularına alınmıştır. Elde edilen verilere Düzgüneş ve ark. (1983) tarafından bildirildiği şekilde varyans analizi ve Duncan testi uygulanmıştır. Embriyogenik kalluslarda SGO'ya alındıktan yaklaşık 4-5 hafta sonra sürgün uçları gözükmeye başlamış olup, sürgünler gelişinceye kadar SGO'da bırakılmıştır (Şekil 2.e.). Farklı hormon konsantrasyonlarının, sürgün rejenerasyonu oranı üzerine etkileri 0.01 düzeyinde istatistiki olarak önemli bulunmuştur. Farklı BAP, KIN, NAA ve IBA konsantrasyonlarının sürgün rejenerasyonu üzerinde önem düzeyini belirleyebilmek amacıyla kullanılan tüm 
ortamlarda, Duncan testi yapılmış ve sonuçlar (Çizelge

5)'te verilmiştir.
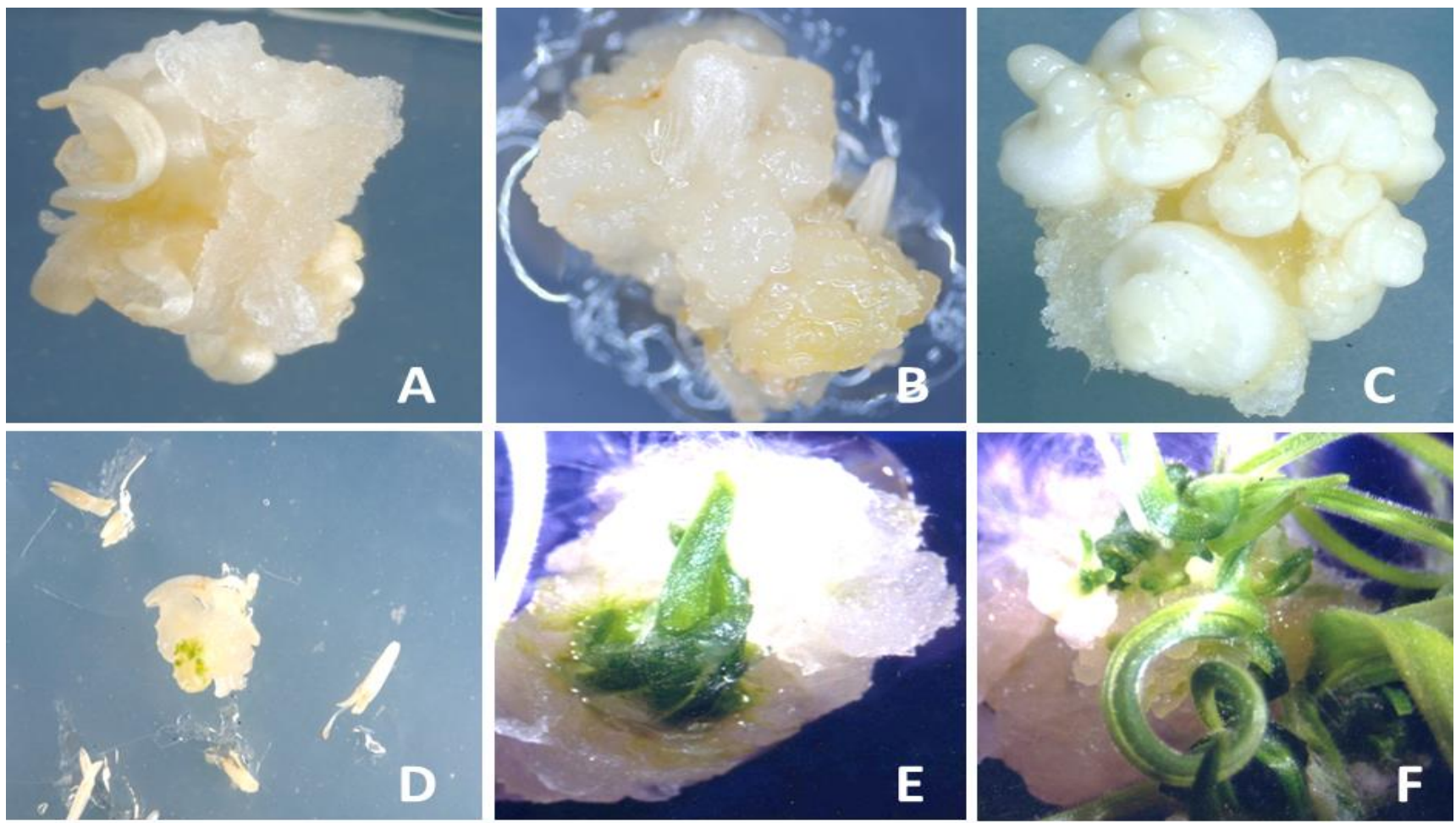

Şekil 2. Buğday çeşitlerinde embriyonik kallus ve sürgün oluşumu a) Kültür başlangıcından 8-10 hafta sonra Tosunbey çeşidinde kallus oluşumu b) Kültür başlangıcından 8-10 hafta sonra Demir-2000 çeşidinde kallus oluışumu c) Bayraktar2000 çeşidi anterleri üzerinde embriyonik/kompakt kallus oluşumu d) Tosunbey çeşidinde Embriyogenik kallusların SGO'ya alındıktan yaklaşık 6 hafta sonra sürgün uçlarının görülmeye başlaması e) Demir-2000 çeşidinde embriyogenik kalluslar SGO'ya alındıktan yaklasık 4-5 hafta sonra sürgün uçlarının görülmeye başlaması f) Tosunbey çeşidinde embriyonik kalluslar SGO'ya alındıktan yaklaşık 12 hafta sonra sürgünlerin uzaması

Figure 2. Embryogenic callus clusters and shoot formation in the wheat varieties a) callus formation in Tosunbey variety after 8-10 weeks culture initiation b) Callus formation in Demir-2000 variety after 8-10 weeks culture initiation c) Embryonic/compact callus formation in Bayraktar-2000 variety d) Apperance of shoot tips in Tosunbey variety about 6 weeks later after embryogenic calli are transferred the shoot induction medium e) Apperance of shoot tips in Demir2000 variety after 4-5 weeks embryogenic calli are transferred the shoot induction medium f) Extension of the adventitious shoots in Tosunbey variety approximately after 12 weeks embryonic calli were transferred to the shoot induction medium 
Çizelge 4. Farklı kallus teşvik ortamları (KTO) ve ön soğuk uygulamalarının Demir-2000 çeşidinde kallus oluşumu üzerine etkileri (\%)

Table 4. Effects of different callus induction media and pre-cold treatments on callus formation in Demir-2000 variety (\%)

\begin{tabular}{lcccc}
\hline \multirow{2}{*}{ Besin Ortamları } & \multicolumn{3}{c}{ Ön soğuk uygulaması (gün) } & \multirow{2}{*}{ Ortalama } \\
\cline { 2 - 4 } & 0 & 4 & 7 & $2.5 \mathrm{a}$ \\
KTO $\left(\mathrm{M}_{1}\right)$ & $0.0 \mathrm{e}$ & $3.0 \mathrm{bcd}$ & $4.5 \mathrm{ab}$ & $0.2 \mathrm{~b}$ \\
KTO $\left(\mathrm{M}_{2}\right)$ & $0.0 \mathrm{e}$ & $0.0 \mathrm{e}$ & $0.5 \mathrm{e}$ & $0.3 \mathrm{~b}$ \\
KTO $\left(\mathrm{M}_{3}\right)$ & $0.0 \mathrm{e}$ & $0.0 \mathrm{e}$ & $1.0 \mathrm{de}$ & $3.2 \mathrm{a}$ \\
KTO $\left(\mathrm{B}_{1}\right)$ & $1.5 \mathrm{cde}$ & $0.0 \mathrm{e}$ & $8.0 \mathrm{a}$ & $0.2 \mathrm{~b}$ \\
KTO $\left(\mathrm{B}_{2}\right)$ & $0.5 \mathrm{e}$ & $0.0 \mathrm{e}$ & $0.0 \mathrm{e}$ & $0.2 \mathrm{~b}$ \\
KTO $\left(\mathrm{B}_{3}\right)$ & $0.0 \mathrm{e}$ & $0.0 \mathrm{e}$ & $0.5 \mathrm{e}$ & $3.0 \mathrm{a}$ \\
KTO $\left(\mathrm{N}_{1}\right)$ & $1.5 \mathrm{cde}$ & $4.5 \mathrm{abc}$ & $3.0 \mathrm{bcd}$ & $0.0 \mathrm{~b}$ \\
KTO $\left(\mathrm{N}_{2}\right)$ & $0.0 \mathrm{e}$ & $0.0 \mathrm{e}$ & $0.0 \mathrm{e}$ & $1.0 \mathrm{~b}$ \\
KTO $\left(\mathrm{N}_{3}\right)$ & $0.0 \mathrm{e}$ & $0.0 \mathrm{e}$ & $3.0 \mathrm{cde}$ & \\
Ortalama & $0.4 \mathrm{~b}$ & $0.8 \mathrm{~b}$ & $2.3 \mathrm{a}$ &
\end{tabular}

LSD \% 5 besin ortamları = 3.504; LSD \% 5 ön soğuk uygulaması $=2.023 ;$ LSD $\% 5$ interaksiyon $=6.07$

Çizelge 5'te de görüldüğü gibi, sürgün rejenerasyon oranı (sürgün oluşturan eksplant oranı), \% 00.00-.5.0 arasında değişmiştir. En yüksek sürgün rejenerasyon oranı (\% 5.0) $2 \mathrm{mg} \mathrm{L}^{-1} \mathrm{KIN}$ ve $0.50 \mathrm{mg} \mathrm{L}^{-1} \mathrm{IBA}$ içeren ortamda gözlenmiştir. Bunu \% 2.5 ile $2 \mathrm{mg} \mathrm{L}^{-1} \mathrm{KIN}$ ve $0.50 \mathrm{mg} \mathrm{L}^{-1}$ NAA içeren ortamı izlemiştir. Besin ortamları, sürgün rejenerasyonu bakımından, 0.01 düzeyinde 2 grup içerisinde yer almışlardır.

Çizelge 5. Farklı büyüme düzenleyici konsantrasyon ve kombinasyonlarının Demir-2000 çeşidi anterlerinde sürgün oluşumu üzerine etkileri

Table 5. Effects of different growth regulators concentrations and combinations on shoot formation in Demir-2000 variety

\begin{tabular}{|c|c|c|c|c|}
\hline \multicolumn{4}{|c|}{ Büyüme düzenleyicileri $\left(\mathrm{mg} \mathrm{L}^{-1}\right)$} & \multirow{2}{*}{ Sürgün oluşturan anter oranı (\%) } \\
\hline BAP & Kinetin & NAA & IBA & \\
\hline 1.0 & - & 0.25 & - & $0.0 \mathrm{~b}$ \\
\hline 2.0 & - & 0.50 & - & $0.0 \mathrm{~b}$ \\
\hline 1.0 & - & - & 0.25 & $0.0 \mathrm{~b}$ \\
\hline 2.0 & - & - & 0.50 & $2.5 a b$ \\
\hline- & 1.0 & 0.25 & - & $0.0 \mathrm{~b}$ \\
\hline- & 2.0 & 0.50 & - & $0.0 \mathrm{~b}$ \\
\hline- & 1.0 & - & 0.25 & $0.0 \mathrm{~b}$ \\
\hline- & 2.0 & - & 0.50 & $5.0 \mathrm{a}$ \\
\hline
\end{tabular}

LSD $\% 5=7.704$

Bayraktar-2000 çeşidi anterlerinin in vitro'da kültüre alınması ve embriyonik kallus oluşumu

2000 yılında TARM tarafından tescil ettirilen Bayraktar 2000 çeşidinde kullanılan tüm besin ortamları ve ön soğuk muamelelerinde ortalama kallus oranı \% 0-5.0 arasında değişmiştir (Çizelge 6). Farklı temel besin ortamlarının ve ön soğuk uygulamasının kallus oluşumu üzerine etkileri incelendiğinde sadece 7 gün süreyle ön soğuk muamelesi yapılan ve KTO $\left(M_{1}\right)$ ve KTO (BI) sıvı ortamında kültüre alınan anterlerde çok düşük düzeyde kallus oluşumu (sırasıyla \% 5.0 ve \%3.5) tespit edilmiştir. Sadece 2 ortam ve 7 gün süreyle ön soğuk uygulaması yapılan anterlerde çok düşük düzeyde kallus oluşumu belirlendiği için istatistiki analiz yapılmamıştır. Kültür başlangıcından 10 hafta sonra anterler üzerinde embriyonik kallus oluşumu görülmüştür. Embriyogenik kalluslar sürgün oluşumu başlayıp sürgünler gelişinceye kadar SGO da bırakılarak 3 haftada bir besin ortamı yenilenmiştir. $M_{1}$ besin ortamından 7 gün süreyle soğukta muhafaza edilen anterlerden kallus üzerinde oluşan 1-2 mm çapındaki embriyoidler içeren anterler ile kallus oluşturmayan anterler karışık olarak, MS mineralleri ve vitaminleri çeşitli konsantrasyonlarda sitokinin (BAP ve Kinetin) ve oksinler (IBA ve NAA), \% 2 
sukroz ve $7 \mathrm{~g} \mathrm{~L}^{-1}$ agardan oluşan sürgün gelişim ortamına (SGO) aktarılmıştır. Embriyogenik kalluslarda sürgün oluşumu başlayıp sürgünler gelişinceye kadar SGO da bırakılarak 3 haftada bir besin ortamı yenilenmiştir.

Çizelge 6. Farklı kallus teşvik ortamları (KTO) ve ön soğuk uygulamalarının Bayraktar-2000 çeşidinde kallus oluşumu üzerine etkileri (\%)

Table 6. Effects of different callus induction media and pre-cold treatments on callus formation in Bayraktar-2000 variety (\%)

\begin{tabular}{lcccc}
\hline \multirow{2}{*}{ Besin Ortamları } & \multicolumn{3}{c}{ Ön soğuk uygulaması (gün) } & \multirow{2}{*}{ Ortalama } \\
\cline { 2 - 4 } & 0 & 4 & 7 & 1.66 \\
KTO $\left(\mathrm{M}_{1}\right)$ & 0.0 & 0.0 & 5.0 & 0.0 \\
KTO $\left(\mathrm{M}_{2}\right)$ & 0.0 & 0.0 & 0.0 & 0.0 \\
KTO $\left(\mathrm{M}_{3}\right)$ & 0.0 & 0.0 & 0.0 & 1.16 \\
KTO $\left(\mathrm{B}_{1}\right)$ & 0.0 & 0.0 & 3.5 & 0.0 \\
KTO $\left(\mathrm{B}_{2}\right)$ & 0.0 & 0.0 & 0.0 & 0.0 \\
KTO $\left(\mathrm{B}_{3}\right)$ & 0.0 & 0.0 & 0.0 & 0.0 \\
KTO $\left(\mathrm{N}_{1}\right)$ & 0.0 & 0.0 & 0.0 & 0.0 \\
KTO $\left(\mathrm{N}_{2}\right)$ & 0.0 & 0.0 & 0.0 & 0.0 \\
KTO $\left(\mathrm{N}_{3}\right)$ & 0.0 & 0.0 & 0.0 & \\
\hline Ortalama & 0.0 & 0.0 & 2.83 & \\
\hline
\end{tabular}

Ancak hiçbir sürgün geliştirme ortamında sürgün ucu primordiası gözlenmemiştir. Çeşitlerin androgenetik kapasiteleri bakımından karşılaştıııldığında kullanılan genotipler kallus ve sürgün oluşum oranı bakımından farklı tepkiler vermişlerdir. Araştırma sonuçlarına göre Tosunbey çeşidinin Demir-2000 ve Bayraktar-2000 çeşidine göre kallus oluşturma kapasitesinin daha iyi olduğu saptanmıştır. Bunun yanında özellikle Bayraktar2000 çeşidinin düşük kallus oluşturma kapasitesi dikkate değerdir. Ayrıca Demir-2000 çeşidinde Bayraktar ve Tosunbey çeşitlerine göre daha erken kallus oluşumu gözlenmiş, Demir-2000 çeşidinde daha hızlı ve daha kompakt kallus oluşumu göze çarpmıştır. (Bölük ve Dağüstü, 2003) yaptıkları çalışmada, ekmeklik buğdaylarda yüksek oranda kallus, embriyogenik kallus ve bitki rejenerasyonu üzerine genotip, besin ortamı, ön soğuk uygulaması, donor bitkilerin yetiştirildiği çevre koşullan ve karbonhidrat kaynağı etkili olduğunu bildirmişlerdir. (Gürel ve ark., 1993) yaptıkları çalışmada, resiproksuz olarak diallel melezlenmiş 28 adet makarnalık buğday $F_{1}$ melezi ve 8 adet ekmeklik buğday çeşidine ait anterlerin belirli bir besin ortamına olan reaksiyonlarını incelemişlerdir. Çalışma sonucunda kallus oluşturan anter yüzdeleri bakımından en yüksek değerleri, makarnalık buğday $F_{1}^{\prime}$ lerinde $7 \times 5$ (Islah hattı 1xAltar 84) melezi (\% 14.29), ekmeklik buğdaylarda ise Glenson çeşidi (\% 5.13) vermiştir. Patel ve ark. (2004) yaptıkları çalışmada buğday mikrospor kültüründe kültür koşullarının optimizasyonu üzerinde çalışmışlar ve besin ortamında katılaştırıcı olarak agar yerine gelrite kullanıldığında yüksek frekansta mikrospor kökenli embriyoid elde etmişlerdir. (Liu ve ark., 2002) farklı katılaştırıcıların ve sıvı besi ortamının anter mikrosporlarında kallus oluşumu üzerine farklı etkileri olduğunu bildirmişlerdir. Buna karşılık, bu çalışmada ise her üç temel besin ortamında ( $M S, N_{6}$ ve $B_{5}$ ) da sIVı besin ortamlarının, agar ve gelrite ile katılaştırıımış ortamlarına göre kallus oluşturan anter oranı bakımından Tosunbey ve Demir 2000 çeşitlerinde daha etkili olduğu görülmüştür. Benzer olarak Bayraktar-2000 çeşidinde ise sadece sıvı MS ve $B_{5}$ ortamında kallus oluşmuştur. (Patel ve ark., 2004), CHB ortamının 2,4-D ile kombinasyonunun MC17 ortamından daha iyi sonuçlar verdiği bildirmiştir. (Wang ve Chen, 1986) C17 besin ortamının anter kültüründeki önemini vurgulamışlardır. Bu çalışmadaki bulgulara göre ise, temel besin ortamı tiplerinden özellikle Tosunbey çeşidinde $\mathrm{N}_{6}$ 'nın kallus oluşumu üzerine diğer besin ortamlarından daha etkili olduğu söylenebilir. (Najia ve ark., 1997) Triticum turgidum ssp durum da anter kültürü ile embryo oluşumu ve rejenerasyon protokolünde, başakları 8 gün süre ile $+4^{\circ} \mathrm{C}^{\prime}$ de ön üşütmeye uygun olduğunu rapor etmişlerdir. (Redha ve ark., 2000), haploid bitki frekansını artırmak amacı ile izole edilen anterleri $4{ }^{\circ} \mathrm{C}^{\prime} \mathrm{de}$ 3-14 gün süreyle inkübe etmişlerdir. (Gu ve Liang, 1997) yaptıkları çalışmada, haploid embriyogenik kallustan üretilen protoplastlardan bitki rejenerasyonunu 4$7^{\circ} \mathrm{C}^{\prime}$ de 3-6 gün inkübe edilen başaklardan elde etmişlerdir. Bu çalışmada da her üç çeşitte de 7 gün süre ile $+4^{\circ} C^{\prime}$ de ön üşütmeye bırakılan anterlerde kallus oluşturma oranının bariz bir şekilde arttığı görülmüştür. 
Çalışmada kullanılan yerli çeşitlerin embryonik kallus oluşturma ve sürgün rejenerasyonu bakımından farklı tepkiler verdiği görülmekte, bu androgenetik kapasite farklııklarından ileri gelmektedir. Örneğin ülkemizde yapılan bir çalışmada resiproksuz olarak diallel melezlenmiş 28 adet makarnalık buğday $F_{1}$ melezi ve 8 adet ekmeklik buğday çeşidine ait anterlerin belirli bir besin ortamına olan reaksiyonlarını incelemiş, Anterlerin embryoid oluşturma oranları açsından ise en yüksek değerler makarnalık buğdaylarda $7 \times 5$ (Islah hattı $1 x$ Mexicali) melezinden (\% 55.22) ve ekmeklik buğdaylarda Glenson çeşidinden (\% 5.98) elde edilmiştir (Gürel ve ark., 1993). Pek çok araştırıcı genotipe özgü protokoller geliştirerek farklı frekanslarda haploid bitki elde etmişlerdir. Tuvesson ve ark. (2000) anter kültürü yöntemi ile buğdayda ortalama 100 anter başına 3.3 buğday haploid bitkisi elde edilmesini başarmışlardır. (Khan ve ark., 2001), kurağa dayanıklı ebevenyler arasında yaptıkları $F_{1}$ melezlerinde \% 12.1'e varan haploid bitki rejenerasyonu elde etmişlerdir. Konieczny ve ark. (2003) 10 adet Polak ekmeklik buğday çeşidinde yaptıkları çalışmada Apollo çeşidinde en yüksek (\% 9.1) kallus ve haploid bitki (\% 0.8) elde etmişlerdir. Kullanılan büyüme regülatörleri anter ya da mikrospor kültüründe son derece önemlidir. Buğday mikrosporlarının embryonik kallus ve sürgüne evrilebilmesi için genotipe uygun bir oksin-sitokinin dengesinin sağlanması pek çok araştırıcı tarafından ortaya konmuştur. Farklı araştırıcılar tarafından buğdayda mikrospor kültüründe sürgün oluşumunu teşvik etme amacı ile birbirinden farklı oksin/sitokinin kombinasyonları kullanılmıştır (Gu ve Liang, 1997; Hansen ve Andersen, 1998; Tuvesson ve ark., 2000; Khan ve ark., 2001; Abdallah ve ark., 2012; Lantos ve ark., 2013; Asif ve ark., 2014). Buğdayda mikrospor kültüründe özelikle bazı oksinlerin önemi vurgulanmıştır (Zheng ve Konzak, 1999; Patel, 2004) buğdayda anter kültürü için $1 \mathrm{mg} \mathrm{L}^{-1} B A P$ ve $1 \mathrm{mg} \mathrm{L}^{-1} \mathrm{IAA}$ içeren besin ortamının uygun olduğunu bildirmiştir. $\mathrm{Gu}$ ve Liang (1997) yaptıkları çalışmada, haploid embriyogenik kallustan üretilen protoplastlardan bitki rejenerasyonu için $0.1 \mathrm{mg} \mathrm{L}^{-1} 2,4-\mathrm{D}, 0.5 \mathrm{mg} \mathrm{L}^{-1} \mathrm{NAA}$ ve 1$2 \mathrm{mg} \mathrm{L}^{-1}$ içeren MS rejenerasyon ortamını önerilmiştir. Bu çalışmada da ülkemizde geliştirilen önemli ekmeklik buğday genotiplerinde yüksek frekansta haploid bitki eldesine yönelik oksin ve sitokinin konsantrasyonlarına ve kombinasyonlarına uygun bir ürün rejenerasyonu geliştirilmeye çalışılmıştır. Buna göre Tosunbey çeşidinde en yüksek sürgün rejenerasyon oranı $2 \mathrm{mg} \mathrm{L}^{-1} \mathrm{KIN}$ ve 0.50 $\mathrm{mg} \mathrm{L}^{-1} \mathrm{NAA}, 2 \mathrm{mg} \mathrm{L}^{-1} \mathrm{KIN}$ ve $0.50 \mathrm{mg} \mathrm{L}^{-1}$ IBA elde edilirken, Demir-2000 çeşidinde ise $2 \mathrm{mg} \mathrm{L}^{-1} \mathrm{KIN}$ ve $0.50 \mathrm{mg} \mathrm{L}^{-1} \mathrm{IBA}$ içeren ortamda gözlenmiştir. Her ki çeşitte de, besin ortamına ilave edilen KIN ile IBA ve NAA kombinasyonlarının BAP ile IBA ve NAA kombinasyonlarından sürgün rejenerasyonu bakımından daha olumlu etkilerde bulunduğu görülmüştür.

Ekmeklik buğdayda haploid bitki elde etmek amacıyla yürütülen bu çalışmada, her üç çeşitte de artan ön soğuklanma süresinin kallus oluşum oranına olumlu etkilerde bulunduğu görülmüştür. Her üç temel besin ortamında da sıvı besin ortamlarının, agar ve gelrite ile katılaştırılmış ortamlarına göre Tosunbey ve Demir 2000 çeşitlerinde pozitif etkisi olduğu belirlenmiştir. Ayrıca Tosunbey çeşidinde $N_{6}$ mineral ve vitaminlerini içeren kallus teşvik ortamının kallus oluşumu üzerine diğer besin ortamlarından daha etkili olduğu belirlenmiştir. Elde edilen bu sonuçlara göre, genotipe özgü embriyonik kallus protokollerinin geliştirebileceği olgusunu güçlendirmiştir. Farklı sitokinin tip ve konsantrasyonlarda embriyonik kalluslardan sürgün oluşumu üzerine oksin ve sitokinin kombinasyonlarının çeşitlerde de farklı etkilere sahip olduğu, bu bağlamda bu sonuçlara göre genotipe özgü embriyonik kallus protokollerinin geliştirilmesinin yanı sıra kültür koşullarına ilaveten uygun oksin/sitokinin dengesinin kurularak etkili bir rejenerasyon protokolünün geliştirilebileceği ortaya konmuştur.

\section{ÖZET}

Amaç: $\mathrm{Bu}$ çalışmanın amacl, ekmeklik buğday genotiplerinde haploid bitki eldesine yönelik yüksek frekansta kompakt embriyogenik kallus ve sürgün oluşumu ve farklı temel besin ortamı, katılaştırıcı tipi ve ön soğuk uygulamalarının etkilerini ortaya konulmasıdır. Yöntem ve Bulgular: Çalışmada, Tosunbey, Demir-2000 ve Bayraktar-2000 ekmeklik buğday çeşitleri kullanılmıştır. Anterler 0,4 ve 7 gün süreyle $4^{\circ} \mathrm{C}^{\prime}$ de ön soğuk uygulamasına tabi tutulmuş, daha sonra farklı temel besin ortamlarını ( $M S, N_{6}, B_{5}$ mineralleri ve vitaminleri) içeren ve sıvı, agar ve gelrite ile katılaştırılmış kallus teşvik ortamında kültüre alınmıştır.

Genel Yorum: Araştırma sonuçlarına göre; en yüksek kallus oluşturan anter oranı (\% 14) sıvı $\mathrm{N}_{6}$ besin ortamında 7 gün süreyle soğukta muhafaza edilen Tosunbey çeşidinde elde edilmiştir. Ön soğuklanma süresi artışı embriyonik kallus oluşumuna olumlu etkilerde bulunurken, sıvı besin ortamlarının, agar ve gelrite ile katılaştırılmış besin ortamlarına göre Tosunbey ve Demir 2000 çeşitlerinde pozitif etkisi olduğu, Tosunbey çeşidinde $\mathrm{N}_{6}$ 'nın kallus oluşumu üzerine diğer besin ortamlarından daha etkili olduğu görülmüştür. Gelişen kalluslar daha sonra çeşitli konsantrasyonlarda BAP, KIN, NAA ve IBA içeren MS besi ortamına (sürgün gelişim ortamı) transfer edilmiştir. 
Çalışmanın Önemi ve Etkisi: En yüksek sürgün rejenerasyon oranı (\% 7.5) ile Tosunbey çeşidinde $2 \mathrm{mg}$ $\mathrm{L}^{-1} \mathrm{KIN}$ ve $0.50 \mathrm{mg} \mathrm{L}^{-1} \mathrm{NAA}, 2 \mathrm{mg} \mathrm{L}^{-1} \mathrm{KIN}$ ve $0.50 \mathrm{mg} \mathrm{L}^{-1} \mathrm{IBA}$ içeren MS besin ortamında elde edilmiştir.

Anahtar Kelimeler: Ekmeklik buğday, Triticum aestivum $L$, haploid, anter, $M S, N_{6}, B_{5}$ mineralleri ve vitaminleri.

\section{TEŞEKKÜR}

Bu çalışmanın bir kısmı 1070875 kod numaralı TÜBITAK projesinden desteklemiştir. Desteklerinden dolayı TÜBiTAK'a teşekkür ederiz.

\section{ÇIKAR ÇATIŞMA BEYANI}

Yazar(lar) çalışma konusunda çıkar çatışmasının olmadığını beyan eder.

\section{ARAŞTIRMACILARIN KATKI ORANI BEYANI}

Yazarlar çalışmaya eşit oranda katkı sağlamış olduklarını beyan eder.

\section{KAYNAKLAR}

Abdallah HA, Said AGE, Khalafalla MM (2012) Establishment of an efficient callus induction and plant regeneration system in some wheat (Triticum aestivum L.) cultivars grown in sudan. African Journal of Biotechnology. 11(16): 3793-3799.

Ahmet H, Adak MS (2007) Irak'ta yetiştirilen bazı ekmeklik buğday çeşitlerinde kallus oluşumu ve bitki rejenerasyonu. Tarım Bilimleri Dergisi. 13(3): 285291.

Asif $M$, Eudes $F$, Randhawa $H$, Amundsen $E$, Spaner D (2014) Induction medium osmolality improves microspore embryogenesis in wheat and triticale. In Vitro Cellular \& Developmental Biology-Plant. 50(1): 121-126.

Bölük M, Dağüstü N (2000) Bazı ekmeklik buğday (Triticum aestivum $\mathrm{L}$.) çeşit hat ve kombinasyonlarının anter kültürüne tepkisi. Türkiye 5. Tarla Bitkileri Kongresi, 13-17 Ekim, Diyarbakır Türkiye.

Demarly Y, Sibi M (1989) Amélioration des plantes et biotechnologies. Collection Sciences en marche. AUPELF-UREF, John Libbey Eurotexte, Paris-France. $152 \mathrm{pp}$.

Düzgüneş O, Kesici T, Gürbüz F (1993) İstatistik metotları. Ankara Üniversitesi Ziraat Fakültesi Yayınları No: 862, Ankara-Türkiye.

Gu X, Liang GH (1997) Plantlet regeneration from protoplast-derived haploid embryogenic calli of wheat. Plant Cell Tissue and Organ Culture. 50(2): 139-145.
Khan AJ, Hassan S, Tariq M, Khan T (2001) Haploidy breeding and mutagenesis for drought tolerance in wheat. Euphytica. 120: 409-414.

Konieczny R, Czaplicki AZ, Golczyk H, Przywara L (2003) Two pathways of plant regeneration in wheat anther culture. Plant Cell Tissue and Organ Culture. 73: 177187.

Gürel A, Tosun M, Demir i (1993) Bazı makarnalık ve ekmeklik buğday genotiplerinin anter kültürüne reaksiyonları. Ege Tarımsal Araştırma Enstitüsü Dergisi. 3(2): 98-111.

Hansen NJP, Andersen SB (1998) In vitro chromosome doubling with colchicine during microspore culture in wheat (Triticum aestivum L.). Euphytica. 102(1): 101108.

Jauhar PP, Xu SS, Baezinger PS (2009) Haploidy in cultivated wheats: Induction and utility in basic and applied research. Crop Sci. 49(3): 737-755.

Kim KM, Baenziger PS (2005) A Simple wheat haploid and doubled haploid production system using anther culture. In Vitro Cellular \& Developmental BiologyPlant. 41(1): 22-27.

Lantos C, Weyen J, Orsini JM, Gnad H, Schlieter B, Lein V, Kontowski S, Jacobi A, Mihaly R, Broughton S, Pauk J (2013) Efficient application of in vitro anther culture for different european winter wheat (Triticum aestivum L.) breeding programs. Plant Breed. 132(1): 149-154.

Liu W, Zheng M, Polle E, Konzak C (2002) Highly efficient doubled-haploid production in wheat via induced microspore embryogenesis. Crop Sci. 42(3): 686-692.

Niaja S, Cherkaoui S, Chlyah A, Chlyah H (1997) Embriyo formation and regeneration in triticum turgidum ssp. Durum anther culture. Plant Cell Tissue and Organ Culture. 51(1): 27-33.

Niu Zx, Jiang Ax, Abu Hammad W, Oladzadabbasabadı A, Xu SS, Mergoum M, Elias ME (2014) Review of doubled haploid production in durum and common wheat through wheat $\times$ maize hybridization. Plant Breeding. 133: 313-320.

Patel M, Darvey NL, Marshall DR, Berry JO (2004) Optimization of culture conditions for Improved plant regeneration efficiency from wheat microspore culture. Euphytica. 140: 197-204.

Redha A, Islam SMS, Büter B, Stamp P, Schmid JE (2000) The improvement in regenerated doubled haploids from anther culture of wheat by anther transfer. Plant Cell Tissue and Organ Culture. 63(3): 167-172.

Saidi N, Cherkaoui S, Chlyah A, Chlyah H (1997) Embryo formation and regeneration in Triticum turgidum ssp. durum anther culture. Plant Cell, Tissue and Organ Culture. 51(1): 27-33. 
Snedecor GW, Cochran WG (1967) Statistical Methods. 6th Edition, The lowa State University Press, lowa, USA.

Tuvesson S, Ljungberg A, Johansson N, Kalsson KE, Suijs LW, Josset JP (2000) Large-Scale production of wheat and triticale double haploids through the use of a single-anther culture method. Plant Breeding. 119(6): 455-459.

Wang P, Chen YR (1986) A study on the application of c17 medium for anther culture. Acta Botanica Sinica. 28(1): 38-45.
Zheng MY, Konzak CF (1999) Effect of 2,4Dichlorophenoxyacetic acid on callus induction and plant regeneration in anther culture of wheat (Triticum aestivum L.). Plant Cell Reports. 19: 69-73. 